Article

\title{
Large Deformation Characteristics of Surrounding Rock and Support Technology of Shallow-Buried Soft Rock Roadway: A Case Study
}

\author{
Liu Zhu ${ }^{1,2}$, Qiangling Yao ${ }^{1,2, * \mathbb{D}}$, Qiang $\mathrm{Xu}^{1,2}$, Liqiang $\mathrm{Yu}^{1,2}$ and Qundi $\mathrm{Qu}{ }^{2}$ \\ 1 Key Laboratory of Deep Coal Resource Mining (CUMT), Ministry of Education, Xuzhou 221116, China; \\ zhuliu@cumt.edu.cn (L.Z.); xuqiangck@cumt.edu.cn (Q.X.); TB19020039B1@cumt.edu.cn (L.Y.) \\ 2 School of Mines, China University of Mining \& Technology, Xuzhou 221116, China; ququndi@126.com \\ * Correspondence: yaoqiangling@cumt.edu.cn
}

check for updates

Citation: Zhu, L.; Yao, Q.; Xu, Q.; Yu, L.; Qu, Q. Large Deformation Characteristics of Surrounding Rock and Support Technology of Shallow-Buried Soft Rock Roadway: A Case Study. Appl. Sci. 2022, 12, 687. https://doi.org/10.3390/ app12020687

Academic Editors: Cuiying Zhou and Zhen Liu

Received: 8 December 2021

Accepted: 6 January 2022

Published: 11 January 2022

Publisher's Note: MDPI stays neutral with regard to jurisdictional claims in published maps and institutional affiliations.

Copyright: (C) 2022 by the authors. Licensee MDPI, Basel, Switzerland. This article is an open access article distributed under the terms and conditions of the Creative Commons Attribution (CC BY) license (https:// creativecommons.org/licenses/by/ $4.0 /)$.

\begin{abstract}
The coal resources in the coal-rich area of western China are mostly located in the late diagenetic Cretaceous and Jurassic strata. In this paper, a study on the support of soft rock roadways was carried out in the background of the soft rock track roadway in the Jiebangou coal mine. The field investigation showed that the surrounding rocks of the roadway were weak, soft, and broken, and the surrounding rocks were cemented, with the roadway local deformation exceeding $1 \mathrm{~m}$. The borehole television results showed that the surrounding rocks were mainly weak sandy mudstone and yellow mudstone. The average uniaxial compressive strength of the surrounding rock was $15.49 \mathrm{MPa}$. The roadway is a shallow buried soft rock roadway; site investigation revealed that the original U-shaped steel shed had an extremely low resistance to slip, the filling body behind the U-shaped steel shed fell off, the interaction between the U-shaped steel shed and the surrounding rock was poor, the U-shaped steel shed could not provide sufficient timely support resistance, and the bearing capacity of the U-shaped steel shed was far from consideration. The floor was not effectively supported. The floor had different degrees of the bottom drum, and frequent undercover caused new stress disturbances, which loosened the bottom corners of both rock types and made the shed legs move continuously inward, reducing the bearing capacity and actual support resistance of the bracket. Numerical calculations were performed to study the deformation characteristics of the surrounding rock of the tunnel and the yielding damage characteristics of the brace. The results showed that the current U-shack support strength was insufficient, the two sides were deformed by $950 \mathrm{~mm}$, the bottom of the roadway bulged by $540 \mathrm{~mm}$, and the surrounding rock was mainly shear damaged. The fall of the filler behind the shed caused damage to the U-shaped steel shed spire. Through site investigation results and numerical calculations, the deformation and damage characteristics of the soft rock roadway and its damage causes were analyzed, and the support technology system of 'strengthening support for weak structural parts' was proposed. This improved the mechanical properties of the weak structural support body, the stress state of the local surrounding rock, and the bearing capacity of the support structure, and effectively controlled the deformation, damage, and instability of the surrounding rock of the roadway, and deformation, damage, and destabilization of the roadway, thereby achieving overall stability for the surrounding rock of the roadway.
\end{abstract}

Keywords: shallow buried; soft rock; large deformation; U-shaped steel support; stability of surrounding rock

\section{Introduction}

The shallow coal resources in the eastern mining areas of China are gradually depleting, making the western mining areas the main coal resource. Most of the western coal resources occur in the Cretaceous and Jurassic strata, where the roof and floor of the coal seams are mostly composed of weakly cemented rocks, such as mudstone, shale, argillaceous 
sandstone, and mud-sandstone interbeds. Such rocks are composed of abundant clay minerals with water-absorbent and expansive properties, and have numerous pores and cracks, making them soft, muddy, and they disintegrate easily under interactions with water and rock, causing the strength of the rock to decrease. This renders the roadway to become loose, broken, and unstable, which cannot provide necessary support during mining, increasing high maintenance costs and multiple repairs in the later period, inversely impacting safe and efficient coal production, and increasing the costs of the coal mine.

Stable support is the key to mining in soft rock roadways [1]. Several studies have been conducted on soft rock roadways in coal mining [2-4]. The poor mechanical properties of the surrounding rock directly lead to the deformation of soft rock roadways by the development of cracks in the surrounding rock [5] and weathering and oxidation of coal seams [6]. Rocks surrounding the coal seams are generally very weak [3,7]. Increasing mining depth due to high in-situ stress, high overburden, and tectonic stress causes the surrounding rock to undergo large nonlinear deformation [8], making it soft [9], e.g., the Pingdingshan mining area [10], Yili No. 1 Coal Mine [11], Xiaokang Coal Mine [12], Xin'an coal mine in Gansu Province $[13,14]$. Roadways experience large deformations, such as layered soft rock roadways [15], cross roadways [16], close coal seam roadways [17], and steeply inclined rock layer roadway [18-20] due to complicated geological structures. Mining disturbance also contributes to a dramatic deformation of the roadway [21,22]. Water-based erosion in a water-rich roadway reduces its strength and serviceability [23,24]. Bottom dilation is a common feature for the deformation of soft rock roadways [25-27]. Experimental and theoretical analyses have been used to understand the mechanism of large deformation of soft rock [28-30], based on which a series of combination support schemes have been proposed [31-33]. Among them, grouting support is widely used because of its good performance [34-36].

The surrounding rock of the Jiebangou coal mine roadway is weak, soft, broken, and behaves like mud with water. Initially, the support parameters were selected based on the theoretical calculation results. However, in practical applications, the support system failed, and the surrounding rock is deformed significantly. In this study, a research method, combining field investigation, theoretical analysis, laboratory tests, numerical simulations, and field applications, was adopted to study the deformation and failure characteristics of the surrounding rock of a selected roadway and propose an effective support plan.

\section{Project Overview}

As shown in Figure 1, the Jiebangou coal mine is located in Shanxi Province, China. The north main track roadway is a crossing layer roadway arranged in the No. 4 coal seam (average thickness of $\sim 1.5 \mathrm{~m}$ ) and the roof rock layer. A mudstone layer lies within $30 \mathrm{~m}$ above the roadway, with some weak and extremely thin coal layers. The floor of the roadway is mainly sandy mudstone, and situated within $30 \mathrm{~m}$ of the roadway; Some weak rock layers are sandwiched between extremely thin coal lines and siltstone; soft and broken coal and mudstone occur at the roadway sides of the roadway. The roadway is large with a depth of $\sim 150 \mathrm{~m}$. Roadway excavation revealed yellow mudstone, sandy mudstone, and coal seams as the main rock strata. Wooden planks were used as the filling material behind the support, some sections of which are badly rotten and have fallen off, rendering several gaps between the support and the roadway. 
(a)

(b)
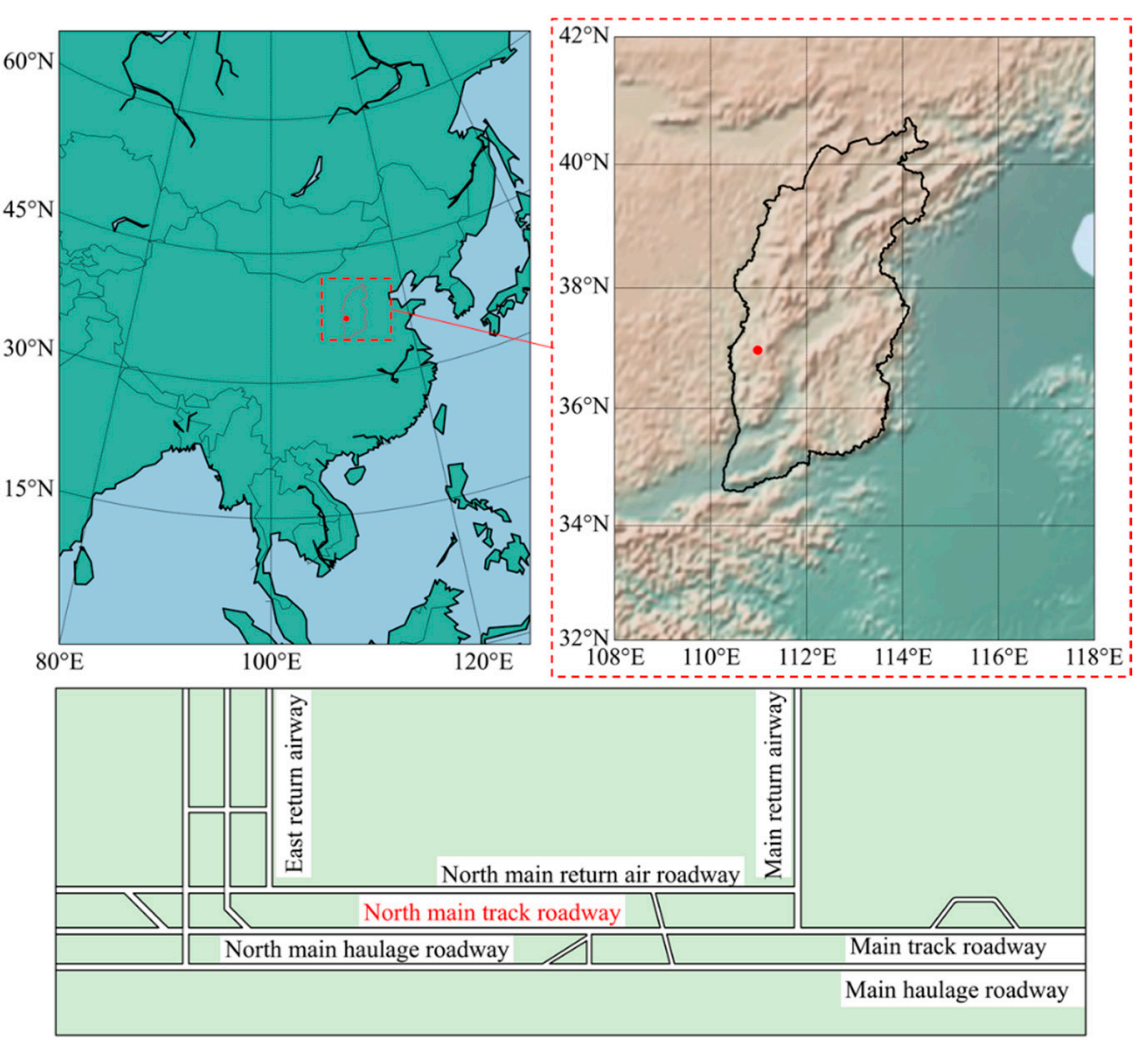

Figure 1. (a) Location of the Jiebangou Coal Mine (b) Plan view of the North main track roadways at the study site in the Jiebangou Coal Mine.

\section{Field Investigation and Laboratory Tests}

\subsection{Damage of the Surrounding Rock Surface}

The support method of the roadway of the north main track roadways is U25 (U represents the section shape and 25 represents the mass per meter), which is an arched steel straight wall with a retractable metal bracket; the spacing between the brackets is $800 \mathrm{~mm}$, and the filling material behind the bracket wall is a wooden board. Field observations revealed a serious overall deformation and damage of the roadway that has significantly reduced the roadway section compared to the designed section of the excavation, which is mainly manifested by different deformation laws in different sections of the roadway, such as roof, floor, and roadway sides. A coal seam or sandy mudstone roadway floor denotes a small deformation for it, while a yellow mudstone roadway floor denotes it is greater; in this case, the deformation of the roadway sides and the roof is greater. In some sections of the roadway, the roof and the roadway sides exhibited different degrees of water splashing; the wood boards behind the support wall were so severely rotten that they had broken and fallen. Water has severely weathered and broke the surrounding rock on the surface of the roadway, and a large number of rock fragments lie between the support and surrounding rock. Owing to the rot of the wood boards, some supports have an empty roof and eccentric loads, causing the supports to deviate and spires to be damaged. The deformation and failure of the roadways and supports are shown in Figure 2.

\subsection{Development of Deep Fracture in the Surrounding Rock}

Since the surrounding rock of the roadway is soft, the rock layer is relatively soft and easily breakable. To better observe the roadway roof and the surrounding rock structure of the roadway sides, the borehole wall observation method was adopted using a TYGD10 borehole detector. To avoid the disturbance of accidental factors, three measuring stations, G1-G3, were arranged at 10, 60, and $90 \mathrm{~m}$ away from the front, respectively. At each measuring station, a $32 \mathrm{~mm}$ wide borehole was arranged on the roof and roadway sides. 
The roof borehole was $6 \mathrm{~m}$ deep and arranged vertically in the middle of the roof; the other two boreholes were $8 \mathrm{~m}$ deep and arranged in the middle of the straight wall at a horizontal angle of $30^{\circ}$ from the roof.

(a)
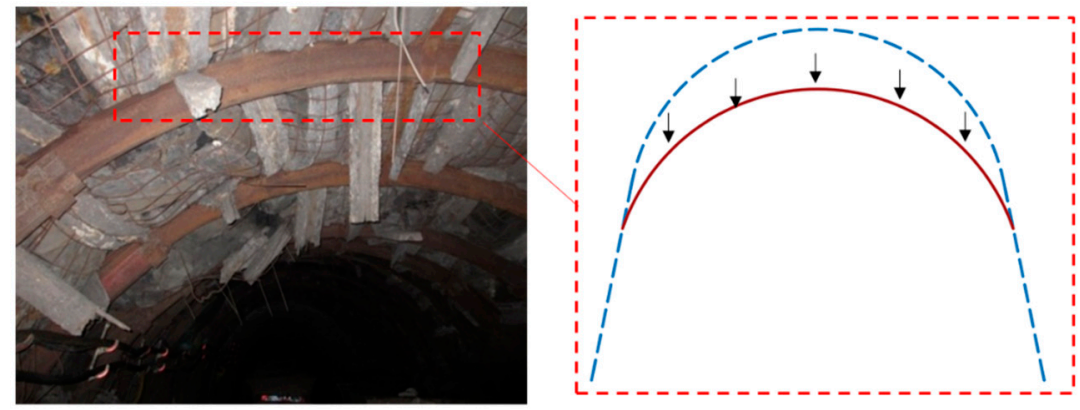

(b)
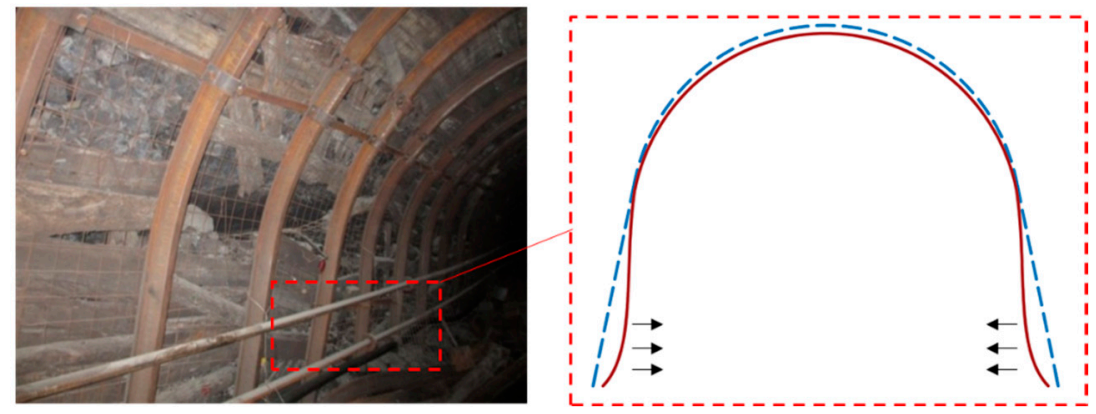

Figure 2. (a) Flattening failure of a U-shaped steel shed top (b) Distortion failure of a U-shaped steel shed foot.

Based on the borehole and on-site measurements (Figure 3), it was inferred that the surrounding rock of the roadway roof has poor integrity, is soft and broken, and contains shallow and deep cracks. The borehole was misty, and the surrounding rock underwent siltification in the water-sprinkling section. In the surrounding rock of the roadway sides, in the relatively complete section, a few cracks had developed in the shallow part, while the integrity of the middle and deep parts was relatively high. The broken section of the roadway showed poor stability, and the horizontal and vertical cracks in the surrounding rock intersected with each other. Additionally, the surrounding rock deformation did not separate the layers. After the excavation of the roadway, the surrounding rock exhibited overall deformation and movement within a certain depth range. Water spraying aggravated the deformation and damage of the roadway. The shallow surrounding rocks on the roof and the roadway sides were variably weathered, and more broken rock fragments were found behind the frame.

\subsection{Laboratory Tests}

The physical and mechanical parameters of coal and rock masses were used for numerical simulation, scheme design, and rock classification. To accurately analyze the mechanism and influencing factors of the deformation and failure of the surrounding rock of the roadway, relatively intact rock samples were selected for the physical and mechanical tests.

Roadway excavation revealed that yellow mudstone has low strength and is easily broken, making it difficult to process them into test blocks for uniaxial compressive tests. Therefore, only the uniaxial compressive strength (UCS) of sandy mudstone was tested. The samples were made into $50 \mathrm{~mm}$ wide and $100 \mathrm{~mm}$ high standard cylinders. Each test group included three rock samples. The test was completed using an electronic universal testing machine. 


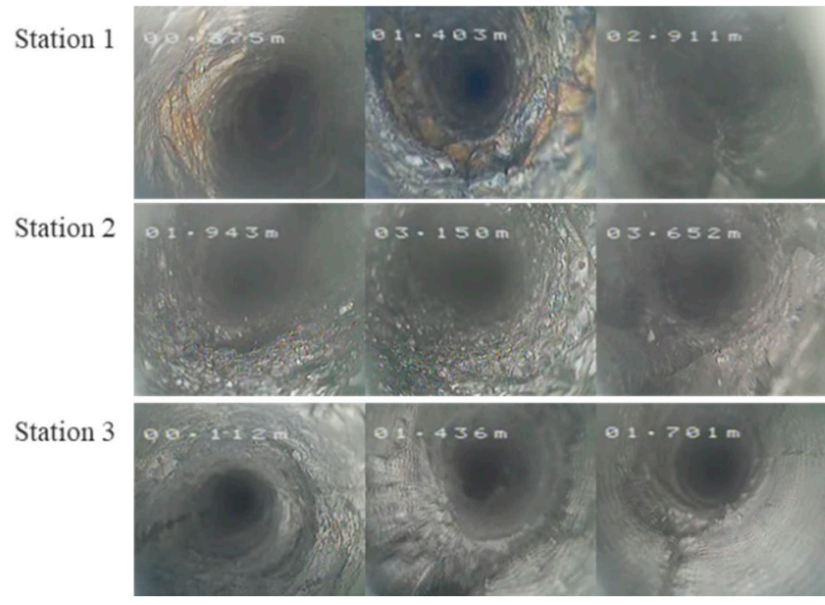

(a)
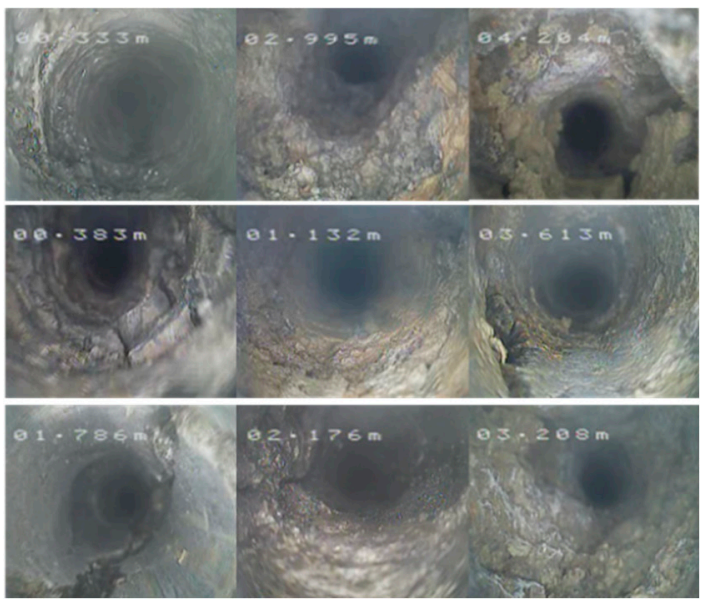

(b)

Figure 3. Fracture patterns of surrounding rocks from borehole television observation (a) Drilling in the roof strata; (b) Drilling in the right rib.

The test results are presented in Table 1 . The average compressive strength of sandy mudstone was $15.49 \mathrm{MPa}$, the average tensile strength was $0.72 \mathrm{MPa}$, and the average shear strength was $3.13 \mathrm{MPa}$; for the yellow mudstone, the average tensile strength was $0.42 \mathrm{MPa}$ and the average shear strength was $1.98 \mathrm{MPa}$. The International Society for Rock Mechanics (ISRM) describes rocks with UCS of 0.25-25 MPa as 'very weak' to 'weak' (ISRM 1981). Kanji [37] considered the upper limit of UCS to be $25 \mathrm{MPa}$ for soft rocks. According to the rock strength classification, both sandy and yellow mudstones are soft rocks, and their unique mechanical properties are extremely detrimental to the stability of the surrounding rock of the roadway.

Table 1. Test results of physical and mechanical parameters.

\begin{tabular}{|c|c|c|c|c|c|c|c|c|c|}
\hline \multirow{4}{*}{$\begin{array}{c}\text { Lithology } \\
\text { Sandy } \\
\text { mudstone }\end{array}$} & \multirow{2}{*}{$\begin{array}{c}\text { Number } \\
1\end{array}$} & \multicolumn{2}{|c|}{ Density $\left(k g / m^{3}\right)$} & \multicolumn{2}{|c|}{$\begin{array}{c}\text { Compressive Strength } \\
\text { (MPa) }\end{array}$} & \multicolumn{2}{|c|}{ Shear Strength (MPa) } & \multicolumn{2}{|c|}{$\begin{array}{c}\text { Tensile Strength } \\
\text { (MPa) }\end{array}$} \\
\hline & & 2433 & & 15.74 & & 3.73 & & 0.32 & \\
\hline & 2 & 2437 & 2413 & 15.00 & 15.49 & 2.56 & 3.13 & 1.23 & 0.72 \\
\hline & 3 & 2368 & & 15.75 & & 3.10 & & 0.6 & \\
\hline \multirow{3}{*}{$\begin{array}{c}\text { Yellow } \\
\text { mudstone }\end{array}$} & 1 & 2115 & \multirow{3}{*}{2072} & \multirow{3}{*}{\multicolumn{2}{|c|}{ I }} & 2.56 & & 0.34 & \multirow{3}{*}{0.42} \\
\hline & 2 & 2097 & & & & 1.75 & 1.98 & 0.56 & \\
\hline & 3 & 2003 & & & & 1.63 & & 0.36 & \\
\hline
\end{tabular}

\section{Numerical Calculations}

\subsection{Model Establishment}

Numerical calculations are commonly used to study engineering problems [38-40]. Based on the failure characteristics of soft rock roadways, we established a simple roadway excavation support model using $\mathrm{FLAC}^{3 \mathrm{D}}$ based on certain assumptions; an appropriate constitutive model was also selected according to the surrounding rock conditions. From the results of laboratory tests and on-site measurements, the model parameters were calibrated to study the general laws of failure of the surrounding rock and support system and propose effective support plans.

The FLAC ${ }^{3 \mathrm{D}}$ model was established according to the actual roadway design (Figure 4). To simplify the model and reduce the boundary influence, a boundary (length $=30 \mathrm{~m}$ ) was set around the roadway. The model was $4 \mathrm{~m}$ long, $64.3 \mathrm{~m}$ wide, and $64.6 \mathrm{~m}$ high. A $4.3 \times 3.37 \mathrm{~m}$ arc arch roadway was adopted, and the beam unit was used to simulate the U-shaped steel frame shed support. A partial excavation method was used to simulate the fall of the shed to support the filling body. The model consists of 28,875 gridpoints 
and 26,700 zones. An overburden rock weight, with an average bulk density of 2.5 was applied to the model. The model was fixed around the model and the horizontal pressure coefficient was 1 .

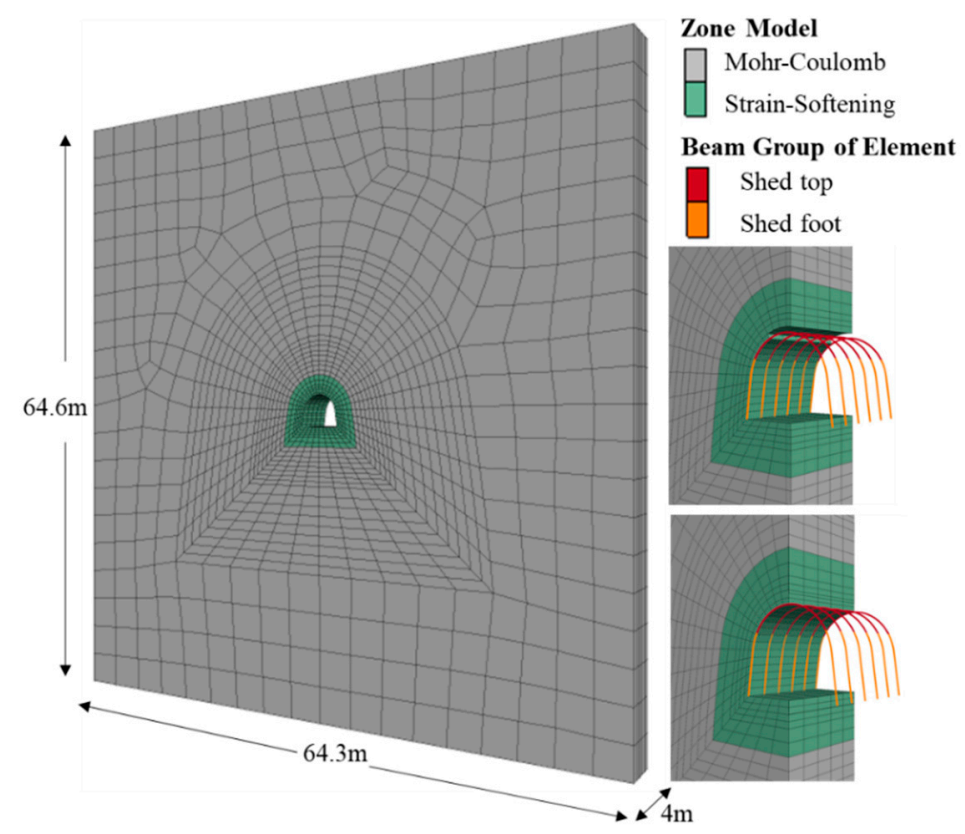

Figure 4. Numerical calculation model.

\subsection{The Constitutive Model and Parameter Calibration}

The Mohr-Coulomb model is typically used to simulate the deformation and failure of engineering rock masses. However, in actual engineering, after the excavation of the roadway, the shallow surrounding rock yields and fails first, and the cracks expand deeper, i.e., strain softening occurs. In the linear phase, the strength parameters of the surrounding rock are significantly reduced. When the stress reaches peak strength with continued deformation, deterioration becomes more prominent. The material parameters in the MohrCoulomb model are always pre-set as constants, but the softening effect due to changes in the surrounding rock parameters cannot be reflected. In the strain-softening model, change in the material cohesion, friction angle, and dilatancy angle with plastic strain is considered, and their relationship can be defined by a piecewise-linear function. Furthermore, the yield criterion, potential function, plastic flow law, and stress correction in this model are identical to those of the Mohr-Coulomb model.

Based on the observations from the drill holes of the surrounding rock within $3 \mathrm{~m}$ of the roadway, a strain-softening model was used to describe the nonlinear mechanical characteristics of the shallow surrounding rock. The Mohr-Coulomb model and the empty model were applied to model the roadway excavation for the deep surrounding rock; simultaneously, the beam element was used to simulate the shed support. The rock mass parameters obtained from laboratory tests could not be directly applied to the numerical calculations. To select the appropriate parameters for the strain softening model, multiple excavation calculations were performed based on the laboratory data to ensure that the deformation of the surrounding rock is consistent with the monitored results. In this study, before the optimization of the roadway support scheme, the roof and floor moved $1000 \mathrm{~mm}$ from each other, and the movement amount used in this model was $1029 \mathrm{~mm}$. The parameters of the Mohr-Coulomb model are listed in Table 2, and the parameters of the strain-softening Mohr-Coulomb model are listed in Table 3. Table 3 shows the variation of cohesion, tensile strength and friction angle with plastic shear strain. 
Table 2. Mechanical properties used in the Mohr-Coulomb model.

\begin{tabular}{ccccccc}
\hline Lithology & $\begin{array}{c}\text { Tensile } \\
\text { Strength } \\
\text { (MPa) }\end{array}$ & $\begin{array}{c}\text { Elasticity } \\
\text { Modulus } \\
\text { (Gpa) }\end{array}$ & $\begin{array}{c}\text { Poisson } \\
\text { Ratio }\end{array}$ & $\begin{array}{c}\text { Density } \\
\mathbf{( k g / \mathbf { m } ^ { 3 } )}\end{array}$ & $\begin{array}{c}\text { Cohesion } \\
\mathbf{( M P a )}\end{array}$ & $\begin{array}{c}\text { Friction } \\
\text { Angle }\left(^{\circ}\right.\end{array}$ \\
\hline $\begin{array}{c}\text { Sandy } \\
\text { mudstone }\end{array}$ & 3.90 & 34.4 & 0.26 & 2535 & 19.10 & 30 \\
\hline
\end{tabular}

Table 3. Mechanical properties used in the strain-softening Mohr-Coulomb model.

\begin{tabular}{|c|c|c|c|c|c|}
\hline $\begin{array}{c}\text { Plastic Shear } \\
\text { Strain }\end{array}$ & 0 & $1 \times 10^{-3}$ & $5 \times 10^{-3}$ & $1 \times 10^{-2}$ & 1 \\
\hline $\begin{array}{c}\text { Cohesion } \\
(\mathrm{MPa})\end{array}$ & 0.5 & 0.3 & 0.2 & 0.1 & 0.5 \\
\hline $\begin{array}{l}\text { Tensile } \\
\text { Strength } \\
(\mathrm{MPa})\end{array}$ & 0.3 & 0.2 & 0.1 & 0.05 & 0.1 \\
\hline $\begin{array}{l}\text { Friction } \\
\text { Angle }\left(^{\circ}\right)\end{array}$ & 28 & 25 & 22 & 19 & 19 \\
\hline
\end{tabular}

\subsection{Results}

\subsubsection{Stress Distribution of the Surrounding Rock}

Owing to the failure of the roadway support system after excavation, the shallow surrounding rock was deformed and damaged, releasing the original rock stress and the stress of the surrounding rock, and further decreasing the bearing capacity of the surrounding rock. This increased the bearing burden of the deep surrounding rock. The data in the middle of the roadway $(Y=2)$ were sliced, and the stress concentration factor was calculated to draw the stress cloud diagram.

Figure 5 shows the stress distribution of the surrounding rock. The stress concentration factor is defined as the stress value at that point divided by the stress before excavation. It was observed that vertical stress was concentrated on the roadway sides of the roadway, with a stress concentration factor of 1.8; the horizontal stress was concentrated on the roof and floor of the roadway, with a stress concentration factor of 1.2. Two monitoring lines A-A' and B-B' were arranged along the X-axis and Y-axis, and the stress on these lines changed with the number of calculation steps (Figure 5). It was observed that vertical stress was concentrated at $4.9 \mathrm{~m}$ below the roadway sides of the roadway. (Figure 6a) With an increase in the number of calculation steps, the vertical stress concentration factor continuously increased and the concentration of stress shifted to the deep part, indicating that the area affected by roadway excavation expands deeper. The calculated depth of the concentrated stress was $13.9 \mathrm{~m}$.

Horizontal stresses were concentrated at the roof at $7.0 \mathrm{~m}$ and the floor at $4.2 \mathrm{~m}$, with rare position changes (Figure 6b). Generally, after roadway excavation, stresses become concentrated in the stable rock layer. The concentration of stresses in the deeper part indicates that it is difficult for the ordinary bolt to provide support.

\subsubsection{Plasticity State of the Surrounding Rock}

In FLAC ${ }^{3 D}$, a conventional Mohr-Coulomb plasticity state indicates two types of failure mechanisms: shear and tensile. A distinct hue represents each category. The graph also shows whether stresses inside a zone are on the yield surface (the zone is currently at active failure, $-n$ ), or whether the zone failed earlier in the model run, but the stresses have now fallen below the yield surface (the zone has failed in the past, -p). Although initial plastic flow may occur at the start of a simulation, further stress redistribution unloads the yielding components, causing their stresses to no longer fulfill the yield requirement, as shown by shear-p or tension-p. 
(a)

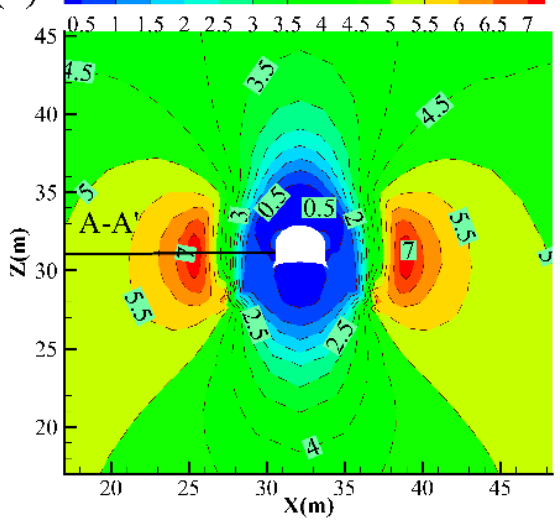

(c)

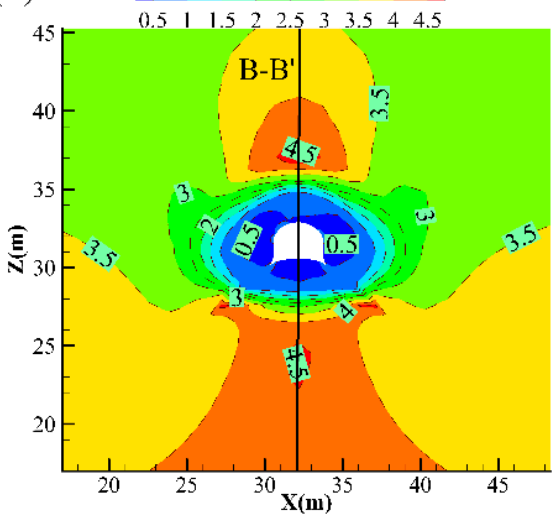

(b)

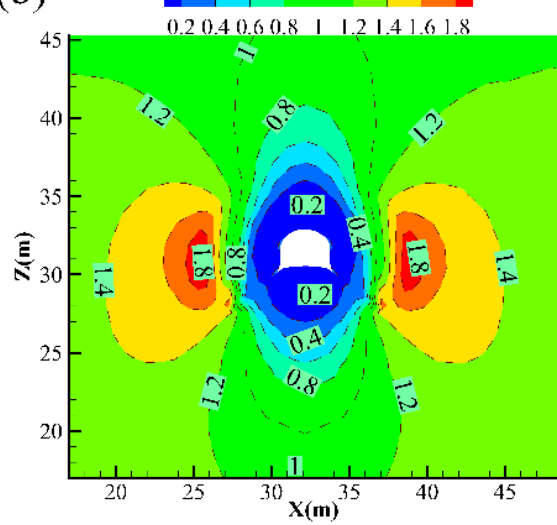

(d)

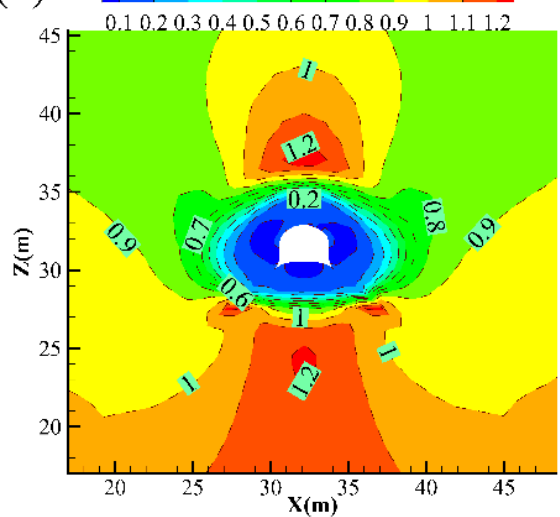

Figure 5. Stress distribution in the surrounding rock. (a) Vertical stress distribution (MPa); (b) Vertical stress concentration factor distribution; (c) Horizontal distribution (MPa); (d) Horizontal stress concentration factor distribution.
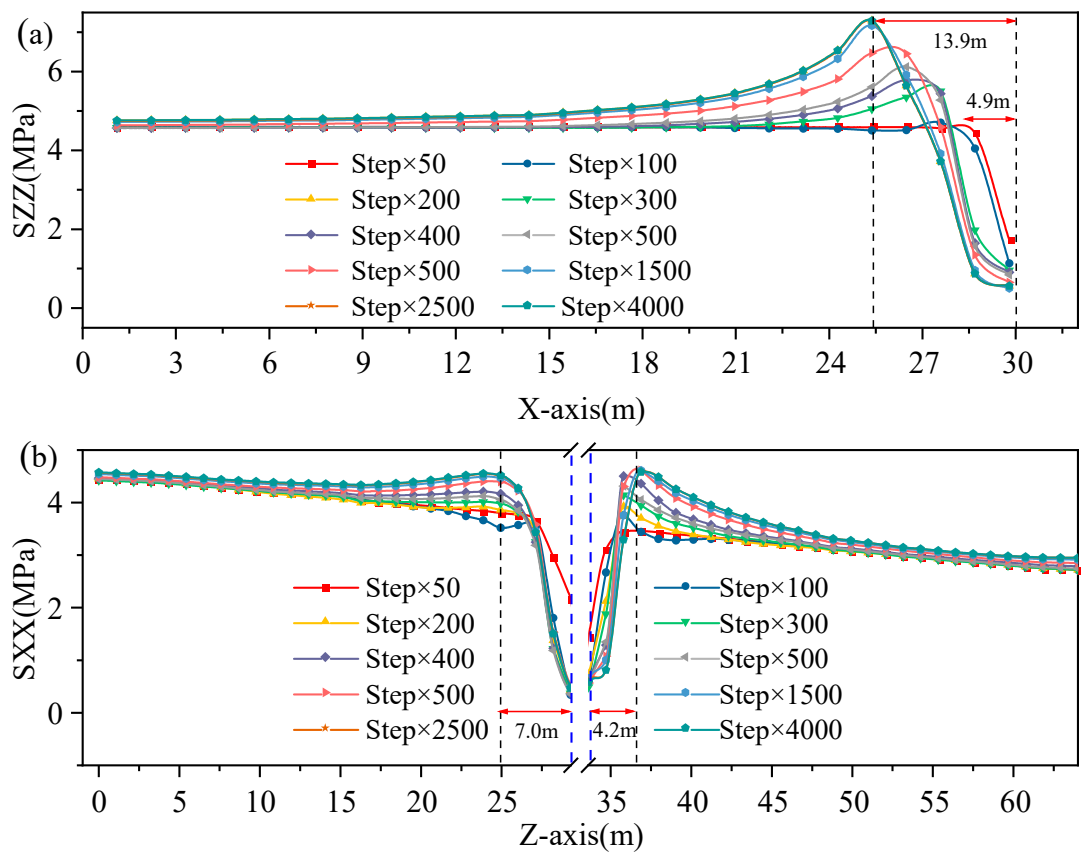

Figure 6. (a) Characteristics of vertical stress on monitoring line A-A' (Figure 5) with calculation steps; (b) Characteristics of horizontal stress on monitoring line B-B' (Figure 5) with calculation steps. 
With an increase in the number of calculation steps in each cycle, both the ratios of the shear and tension failure volumes of the surrounding rock to the excavated volume of the roadway change (Figure 7). Simultaneously, the expansion of the roadway plastic zone was also reflected. After the excavation of the roadway, shear failure occurred mainly in the surrounding rock and tension failure occurred on the floor of the roadway. From the curve in Figure 7, it was observed that in the initial stage of tunnel excavation, shear failure mainly occurs on the roof and floor, and the degree of damage of the floor is larger than that of the roof. With an increase in the number of calculation steps, the volume of shear failure increases linearly, and the tensile failure volume fluctuates. The tensile failure concentrates on the floor due to the gradual failure of the supporting system and the decline in the bearing capacity of the surrounding rock. Because the floor is not supported, the concentrated stress is released from it, causing dilation damage to the floor. Therefore, along with strengthening the support of the sides and roof, the floor should also be strengthened.

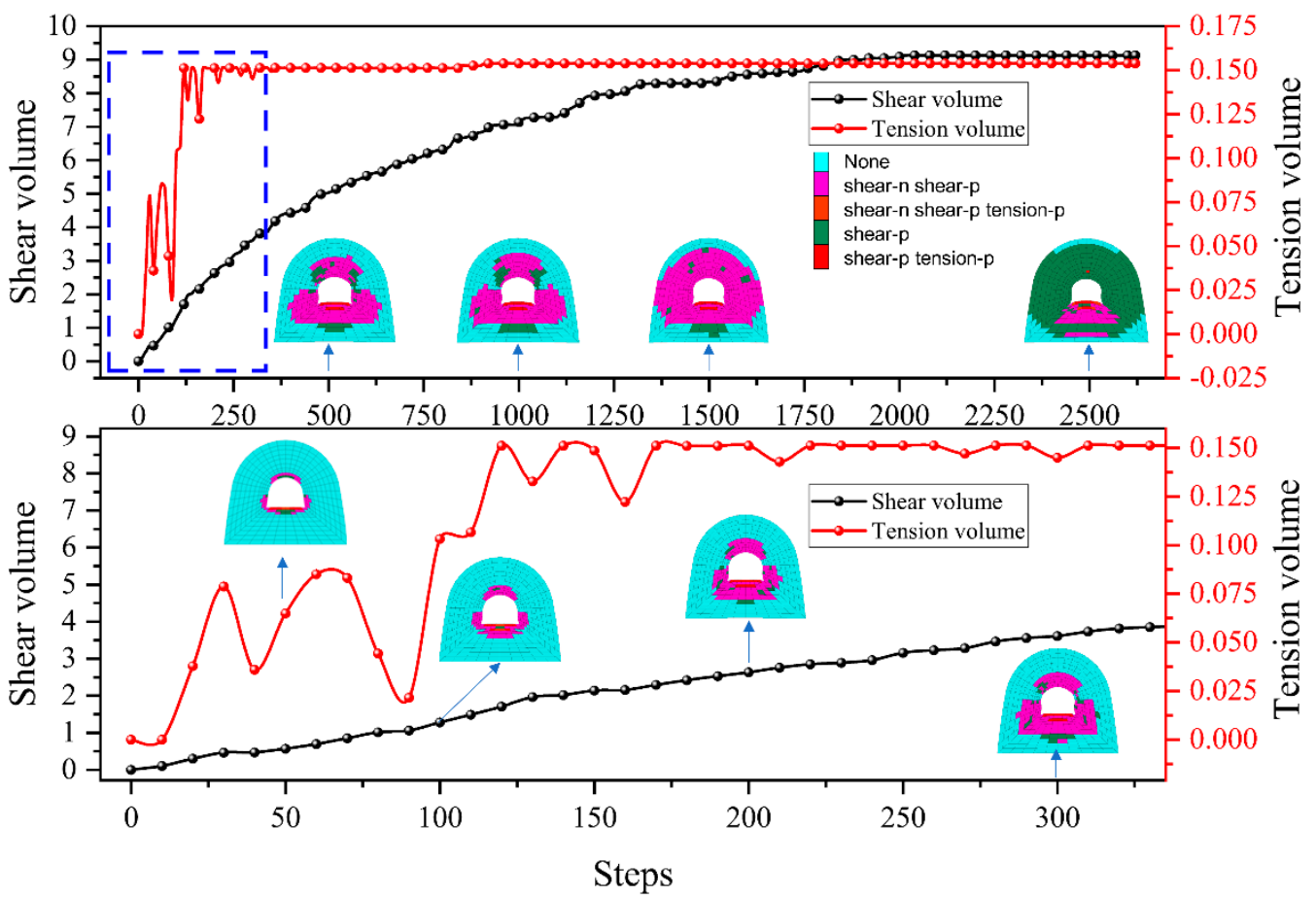

Figure 7. Variation in the ratio of the volume of surrounding rock plastic zone to the excavation area of roadway with an increase in the number of calculation steps.

\subsubsection{Deformation of the Surrounding Rock}

After the excavation of the roadway, the surrounding rock failed, and as the load of the support system continued to increase, the surrounding rock of the roadway deformed significantly. The cloud diagram of displacement for the surrounding rock showed that the roof of the roadway sunk entirely, with prominent displacement and deformation at the position on the roadway sides and near the floor, where maximum deformation was observed on the floor. To fully analyze the deformation characteristics of the surrounding rock, horizontal and vertical deformation cloud maps of the roadway were extracted; the monitoring positions were set at the middle of the roof and floor of the roadway and the middle of the roadway sides to monitor the surface displacement of the roadway. It was observed that the maximum deformation of the roof and floor were 456 and $540 \mathrm{~mm}$, respectively. The deformation of the roadway sides was the same at $445 \mathrm{~mm}$ (Figure 8). Figure 9 shows the deformation curve of the surrounding rock after excavation, where the deformation rate of the roadway gradually decreased, and the floor deformation rate was the fastest, followed by the roof deformation. 
(a)

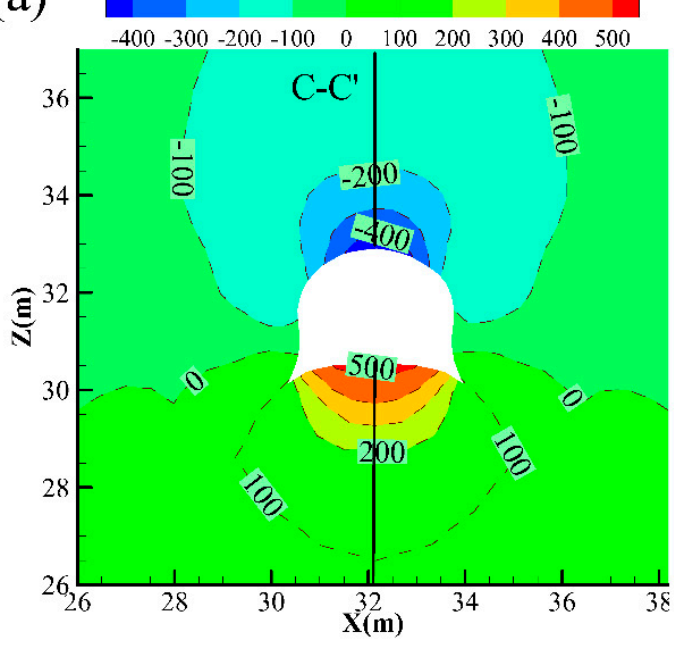

(b)

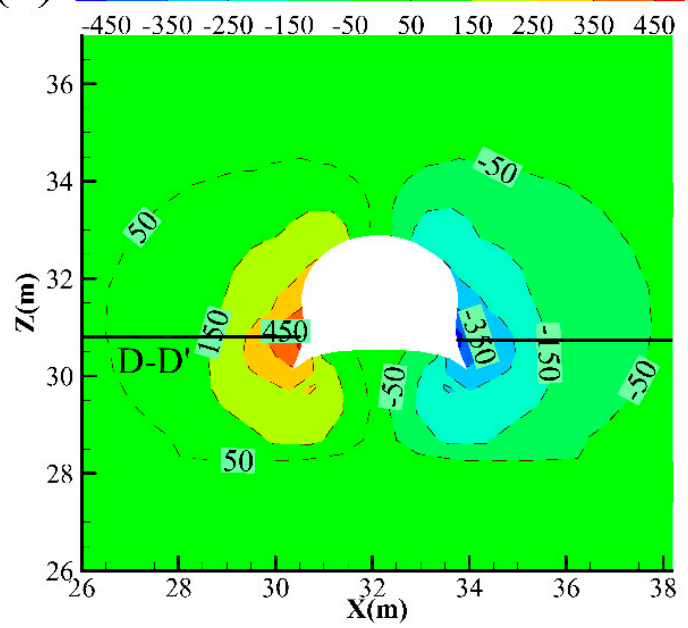

Figure 8. Cloud diagram of (a) vertical displacement; and (b) horizontal displacement.
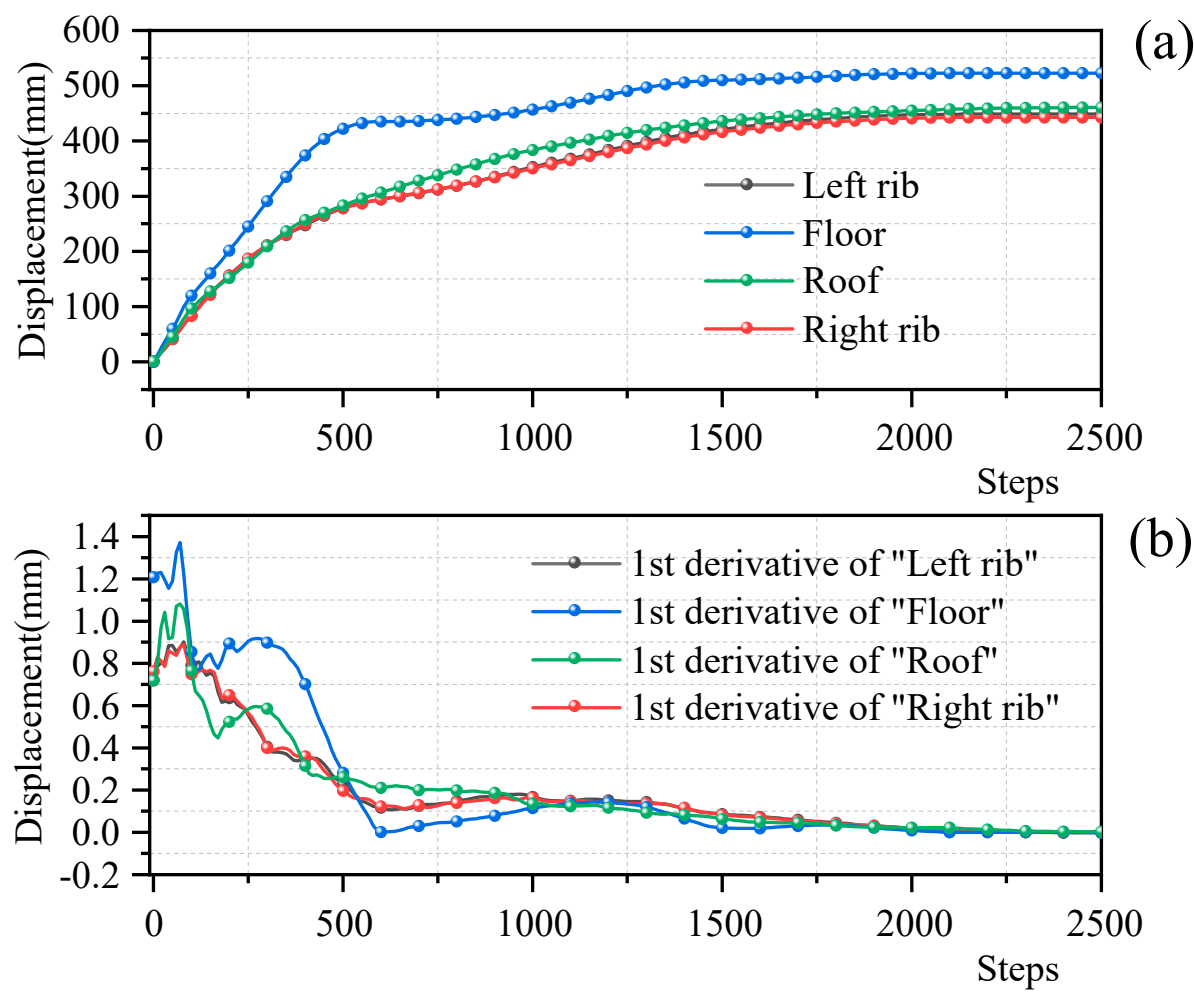

(b)

Figure 9. (a) Deformation of the surrounding rock varying with the number of calculation steps; (b) Deformation rate of the surrounding rock varying with the number of calculation steps.

\subsubsection{Failure Characteristics of the Supporting Structure}

The yield failure of the support system directly caused the large deformation of the roadway. The U-shaped steel shed could not resist the convergent deformation of the roadway (Figure 10); compared to the situation using original support parameters, when the U-shaped steel failed, its roof flattened and damaged, and bending failure of column legs occurred on the roadway sides. It was observed that the U-shaped steel shed was damaged because of the fall of the filling body behind the shed. The criteria for estimating the bending damage of the support steel were as follows: (1) breakage due to shearing, bending, or tension; (2) hard bending in the local range of 15-20 cm; (3) ear sections of the 
steel were warped or twisted; (4) partial or large-scale distortion, and torsional stiffness exceeded $10^{\circ} / \mathrm{m}$. The maximum deformation exceeded $40 \mathrm{~cm}$, and a large yield distortion deformation indicates that the resistance could not be increased normally or failed to support. Eventually, the support was broken and scrapped, which affected the stability, safety, and cost of the support structure.

Beam displacement $(\mathrm{m}) \quad$ Initial support

(a)

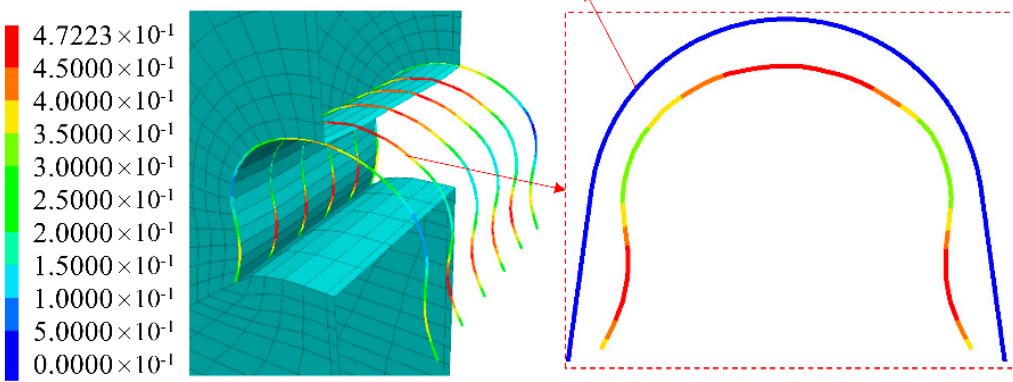

(b)

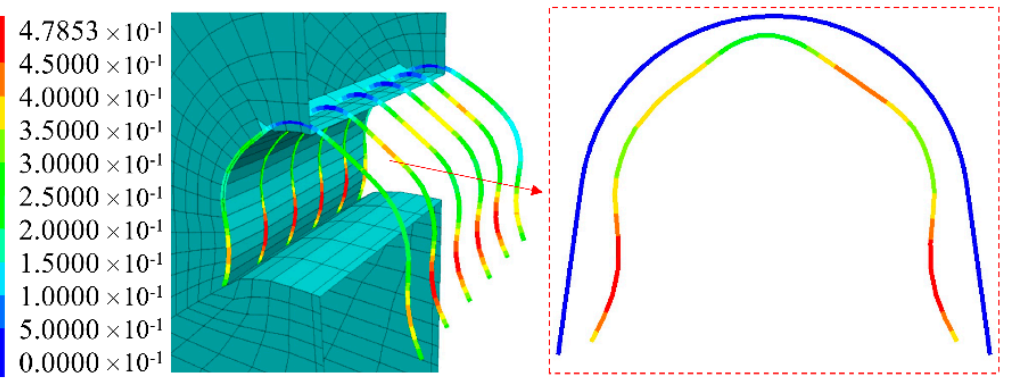

Figure 10. Failure characteristics of the structural elements. (a) complete failure of U-shaped steel shed; (b) roof failure of U-shaped steel shed.

\section{Stability Control Scheme of the Surrounding Rock}

\subsection{Influencing Factor for the Deformation of the Surrounding Rock}

Based on the physical and mechanical properties of coal and rock mass, drilling detection, field observation, hydrogeological conditions of the roadway, and the actual maintenance status, the main influencing factors of the roadway deformation and failure can be concluded as follows:

(1) Influence of the surrounding rock lithology: The coal and rock masses exposed during roadway excavation are all soft rocks with poor strength, stability, and self-supporting ability; this mainly facilitates roadway deformation failure. Additionally, owing to the different degrees of water spraying in the roadway, the surrounding rock variably absorbs water and swells to become muddy, which further deteriorates it.

(2) Influence of the supporting structure: On the one hand, the strength of U25 steel straight wall arched supports arranged at a distance of $800 \mathrm{~mm}$ was not sufficient to effectively limit the deformation of the roadway, which increased the uneven deformation of the roof and the roadway sides; on the other hand, the U-shaped steel support was not in complete contact with the wooden board filling and the surrounding rock, forming point-line contact, and making it easy to bear the hollow load, so the supporting capacity could not be fully utilized.

(3) Influence of the roadway location: The studied roadway is a typical shallow-buried soft rock roadway. The excavation formed a falling arch, and stress was highly concentrated at the roadway sides. Unreasonable support led to a concentration of stresses in the surrounding rocks of the roadway sides, resulting in the expansion of the roof collapse to form a collapsed arch, and the rock load in the collapsed arch continued to be affected by the supporting system. 


\subsection{Control Scheme of the Surrounding Rock}

\subsubsection{The Typical Support Scheme}

Through field observations and numerical calculations, it became clear that the current support system cannot maintain the stability of the surrounding rock. The support strength and method must be improved and optimized. The basic support adopts a highly stable U29 straight wall arch shrinkable three-section arch-type bracket, with a bracket spacing of $800 \mathrm{~mm}$ (Figure 11). The length of the lap section was $400 \mathrm{~mm}$, and a double-slot splint and lower limit clamp cable were used. The compression test showed that at a clamp cable nut torque of $300 \mathrm{~N} \cdot \mathrm{m}$, anti-sliding and shrinking abilities were high, and the bearing load was much smaller than its bearing limit when the bracket was slipping. Therefore, the pre-tightening torque of the cable nut was set at $300 \mathrm{~N} \cdot \mathrm{m}$.

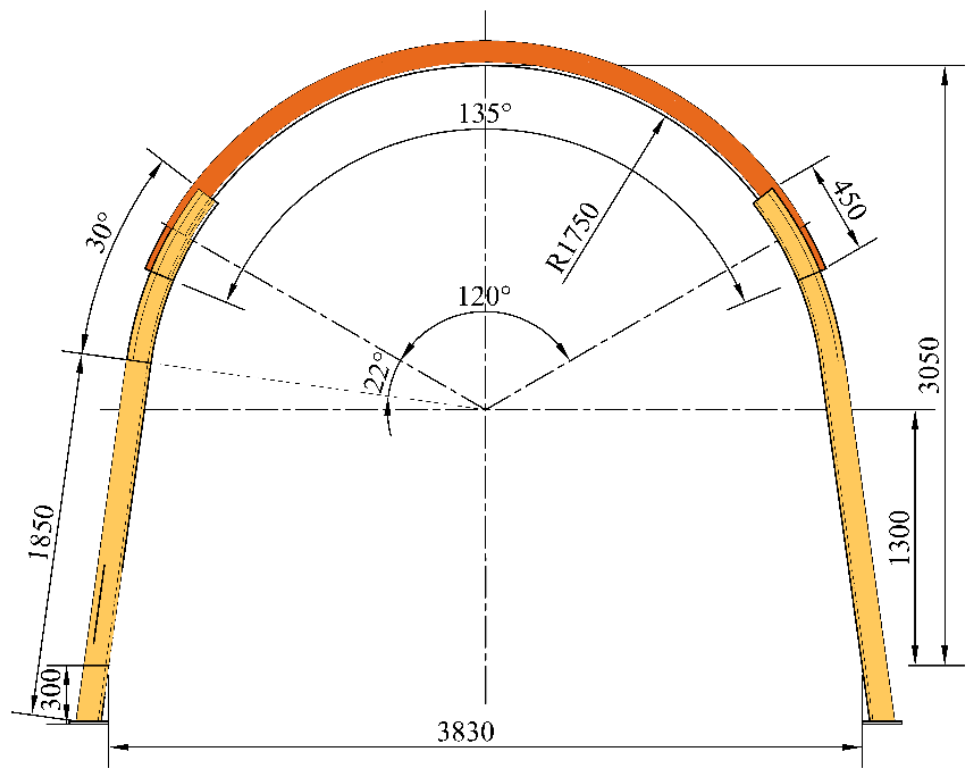

Figure 11. U29 steel shed support parameters.

Furthermore, according to the structural characteristics of the arch, it can be concluded that compared to the situation of the column legs being perpendicular to the base plate bracket, the lateral squeeze resistance enhanced when the column legs were inclined outside; since the lateral stability of the bracket directly impacts on the overall structure stability, straight wall arched brackets with inclined column legs are chosen in engineering. The column leg was inserted into the floor to a depth of $300 \mathrm{~mm}$, and the bottom was welded with a square steel plate base to reduce the specific pressure of the floor. When the floor is particularly soft, wooden pads or stone pads should be added under the column legs to increase the working resistance of the bracket. To prevent rubble from falling and improve the support's ability to protect the surface and provide a good stress environment for it, the support wall was filled with grouting accompanied by a high-strength steel mesh

Small-aperture pre-stressed short anchor cables were used to strengthen the support at the ledge and arch of the roadway to improve the overall bearing capacity and stability (Figure 12). Furthermore, the self-stability ability of the deep rock mass was used to make the support and the surroundings work together. The bank-reinforced anchor cable was $1000 \mathrm{~mm}$ away from the roadway floor, and the arch-reinforced anchor cable was arranged at the top of the vault; 1860 steel stranded wires with a diameter of $17.8 \mathrm{~mm}$ and a length of $6.3 \mathrm{~m}$ were selected as the anchor cable, with a row spacing of $1.6 \mathrm{~m}$. Every two anchor cables were connected by anchor beams made of No. 18 channel steel; the length of the anchor beams was $2400 \mathrm{~mm}$ and the hole spacing was $1600 \mathrm{~mm}$. To ensure the stability of the support structure and adaptability of the anchor cable to the deformation of the surrounding rock, the pre-stress of the strengthened anchor cable should reach $80 \mathrm{kN}$. To 
reduce the weakening effect of weathering on the surrounding rock, $150 \mathrm{~mm}$ thick concrete was shot in time after the support frame.

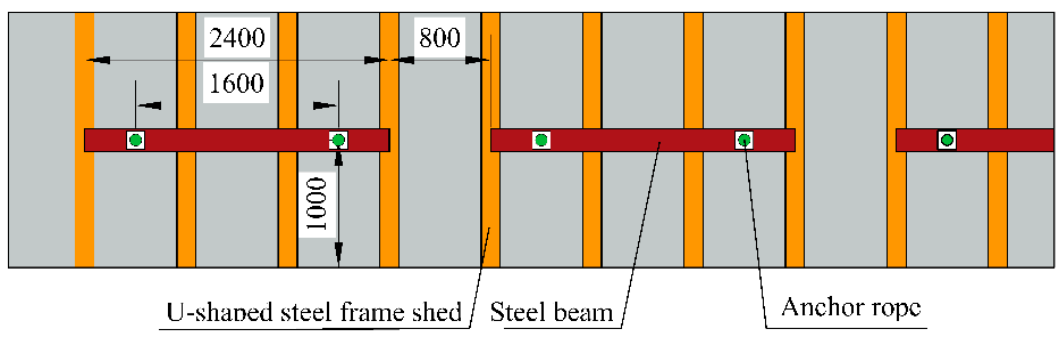

Figure 12. Parameters of the reinforced anchor cable support.

\subsubsection{Support Scheme for the Area with Severe Floor Dilation}

In the area with severe floor dilation, the reverse arch beam, in the form of a twosection arch made of U29 steel, was used to strengthen the floor to control floor deformation (Figure 13). The shrinking movement allowed pressure to work. The inverted arch beam was installed on the bottom surface of the surrounding rock by stripping down $\sim 800 \mathrm{~mm}$ of a broken rock mass. The two sections of the beam, the inverted arch beam and support column legs were fixed by two pairs of double-groove splint limit cables, and the pretightening torque was $300 \mathrm{~N} \cdot \mathrm{m}$. High-strength steel mesh and waterproof materials were combined between the inverted arch beam and the surrounding rock, and the stripped space was filled with a gangue of moderate grain size as a buffer layer.

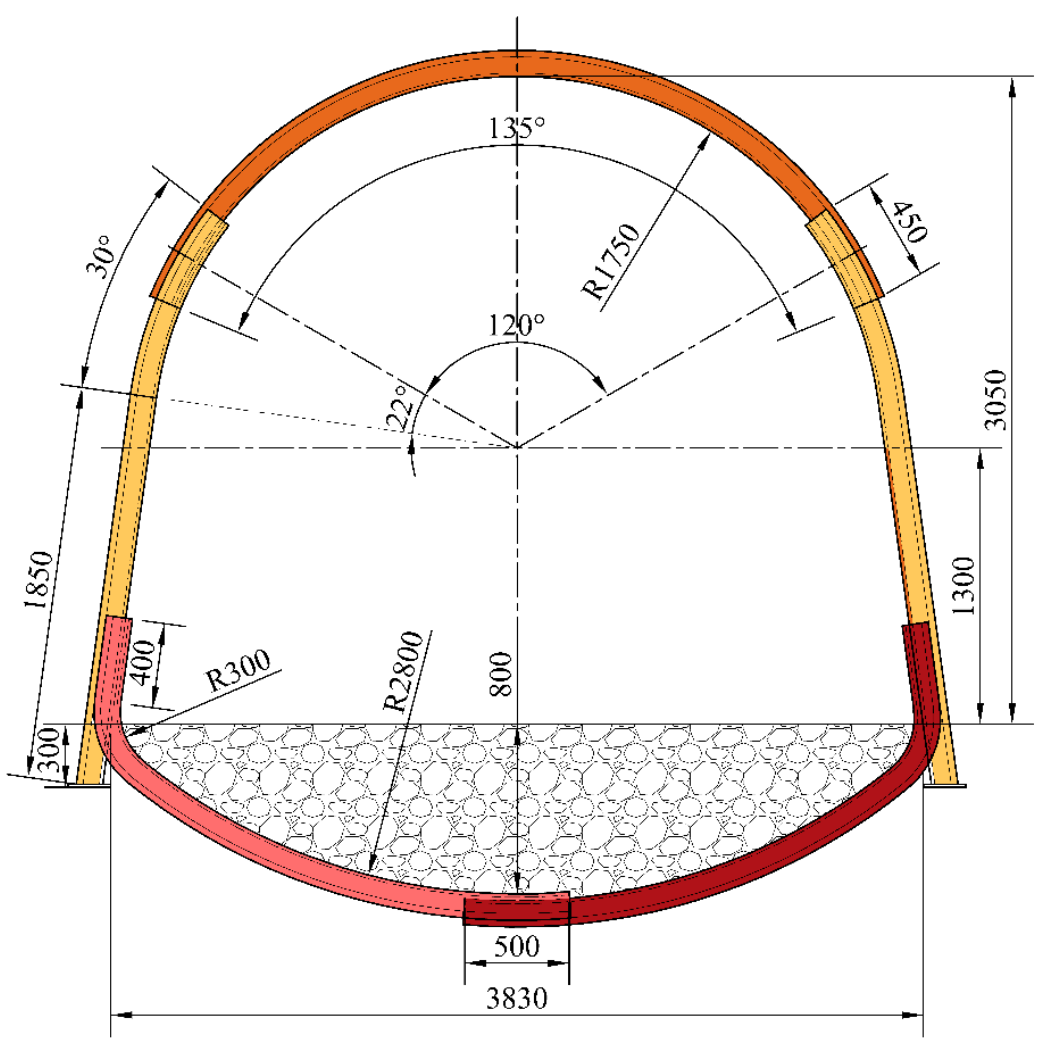

Figure 13. Support parameters of U29 steel shed and floor reverse arch beam.

\subsection{Monitoring the Displacement of the Roadway Surface}

To evaluate the support effect, six measuring stations were arranged in the roadway, among which measuring stations 1,2 , and 4 were arranged in the section without inverted arch beams, and the measuring stations 3,5, and 6 were arranged in the inverted arch 
beam section. Three measuring piles were arranged on the roof, floor, and middle of the roadway sides of each measuring station. The 'cross measurement method' was used to collect the relative movement data of the top and floor and of the roadway sides along with the subsidence of the top and the bottom dilation for $20 \mathrm{~d}$.

The interval between the last construction and monitoring for king stations 1 to 6 since the beginning of the excavation were $43,52,63,74,80$, and $87 \mathrm{~d}$. They missed the initial stage when large deformation occurred; the next stage was the creep deformation stage, and the monitored surface displacement of the surrounding rock of the roadway is shown in Figure 14, where two stations with the largest deformation in the surrounding rock are demonstrated. For station 1, the maximum moving distance of the top and bottom was $48 \mathrm{~mm}$, the maximum moving distance of the roadway sides was $53 \mathrm{~mm}$, the maximum floor dilation was $25 \mathrm{~mm}$. For station 2, the maximum moving distance of the top was $35 \mathrm{~mm}$, the maximum moving distance of the roadway sides was $20 \mathrm{~mm}$, and the maximum bottom dilation was $22 \mathrm{~mm}$. For stations 3-6, the maximum moving distance of the top was $7-15 \mathrm{~mm}$, the maximum moving distance of the roadway sides was $7 \mathrm{~mm}$, and the floor dilation was $<5 \mathrm{~mm}$. Deformation of the roof, bottom, and roadway sides of the roadway suggest that it has a good support effect in the section with or without an inverted arch beam, and the supporting effect of the latter is slightly better.
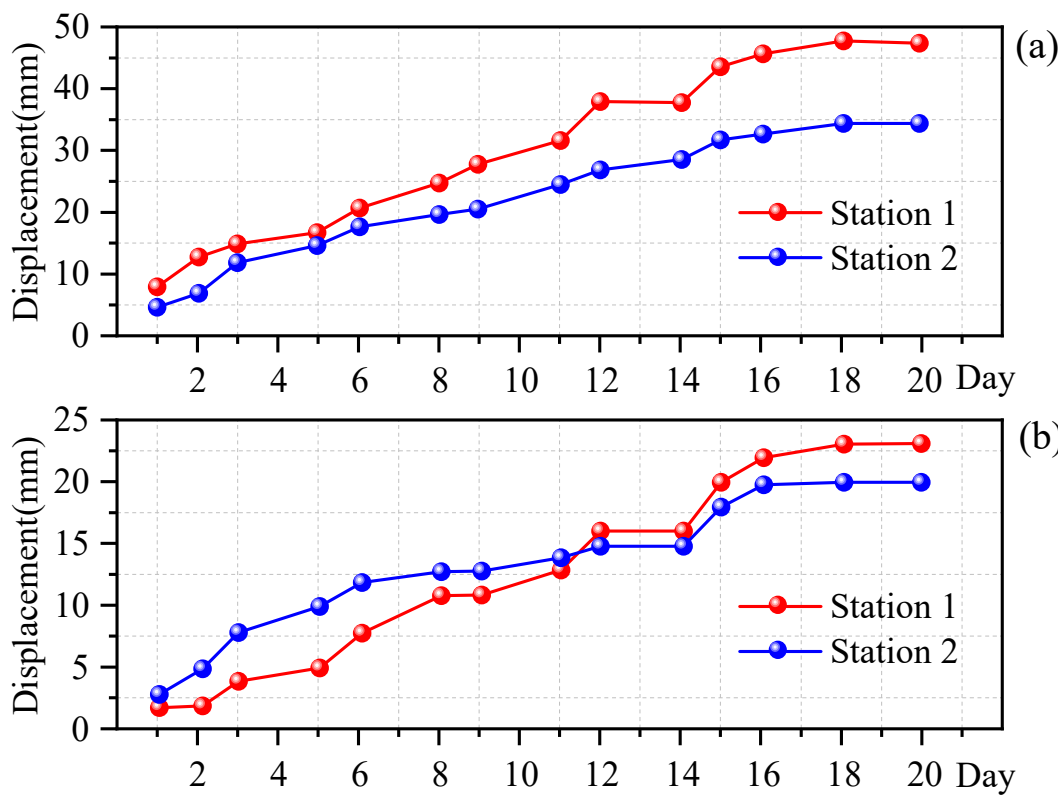

(b)

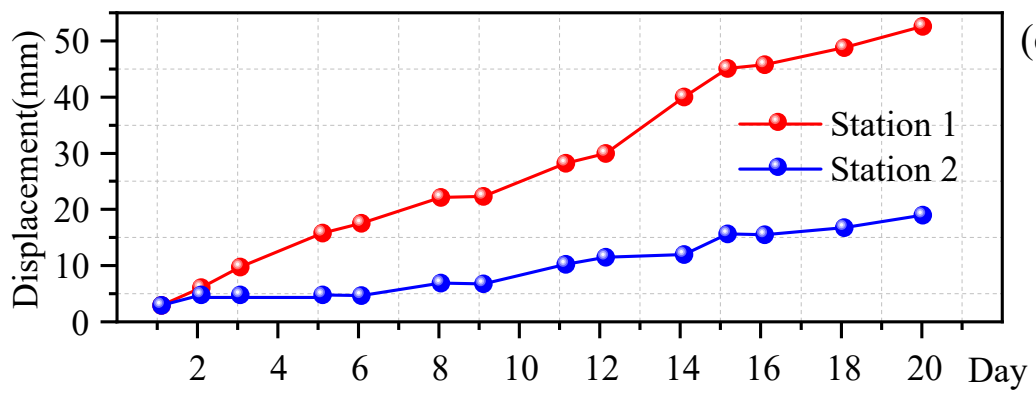

(c)

Figure 14. (a) Approach of roadway roof and floor; (b) deformation of roadway floor (c) approach of two sides of roadway.

\section{Conclusions}

In this study, a highly deformed shallow-buried soft rock roadway in the Jiebangou coal mine was considered as the research subject. By combining field investigations, theoretical analyses, laboratory tests, numerical simulations, and field applications, the failure and instability characteristics of the surrounding rock of the soft rock roadway 
were studied, and an effective control plan for the surrounding rock of the roadway was proposed. The main conclusions are as follows:

(1) Field investigations and roof borehole television results showed that the roof and floor of the north return air track roadway are mainly composed of two types of mudstones, yellow mudstone and sandy mudstone. The rock layer on the surface of the roadway was loose and broken, and the deeper part of the mudstone strata had experienced cementation. The average compressive strength of the mudstone was $15.49 \mathrm{MPa}$, the average tensile strength was $0.72 \mathrm{MPa}$ and the average shear strength was $3.13 \mathrm{MPa}$, which is typical of a shallow-buried soft rock roadway.

(2) Numerical calculations showed that the vertical stress concentrated at both sides of the tunnel, with a stress concentration factor of 1.8 and a depth of $13.9 \mathrm{~m}$. A horizontal stress concentration zone with a factor of 1.2 was formed at $7.0 \mathrm{~m}$ at the top and $4.2 \mathrm{~m}$ at the bottom, with shear damage dominating the surrounding rock and tension damage occurring at the bottom of the tunnel. After excavation, the deformation rate of the floor was maximum, followed by that of the top slab deformation. The lack of bearing capacity of the U-shape steel caused significant deformation of the surrounding rock, and the lack of filling behind the shed caused the U-shape steel shed roof to break down. Failure of the support system caused further deformation of the surrounding rock, especially the floor drum deformation of the roadway.

(3) The trackway was deformed and damaged due to the low strength of the surrounding rock, insufficient strength of the U-shaped steel shed support, and lack of correlation between the U-shaped steel shed and the inability to form a complete unit. The choice of the filling body behind the shed was unreasonable. Therefore, the surrounding rock was controlled by improving the support strength of the roadway, filling the U-shaped steel shed with slurry, increasing the association between the U-shaped steel shed, and preventing the surrounding rock from weathering by spraying slurry on the surface of the roadway. The specific plan was to use the outward sloping form of a straight wall arch retractable bracket of the U29 column leg, with a double-slotted clamp plate upper and lower limit cable. The walls were filled with grout and reinforced with a high-strength steel mesh. A U29 steel counter-arch beam was used to reinforce the floor to control its deformation. Field monitoring showed that this solution could effectively control the deformation of the surrounding rock.

\footnotetext{
Author Contributions: Conceptualization, Q.Y. and Q.Q.; methodology, L.Z.; software, L.Y.; formal analysis, Q.X.; investigation, L.Z.; data curation, L.Z. and Q.X.; writing - original draft preparation, Q.Q.; writing-review and editing, L.Z. and Q.Y.; funding acquisition, Q.Y. All authors have read and agreed to the published version of the manuscript.
}

Funding: National Natural Science Foundation of China: 51874283, 51874285, 51904289.

Conflicts of Interest: The authors declare no conflict of interest.

\section{References}

1. Kang, H.P.; Lin, J.; Fan, M.J. Investigation on support pattern of a coal mine roadway within soft rocks-A case study. Int. J. Coal Geol. 2015, 140, 31-40. [CrossRef]

2. Mcnally, G.H.; Branagan, D.F. Geotechnical consequences of the Newcastle Coal Measures rocks. Aust. J. Earth Sci. 2014, 61, 363-374. [CrossRef]

3. Shen, B. Coal Mine Roadway Stability in Soft Rock: A Case Study. Rock Mech. Rock Eng. 2014, 47, 2225-2238. [CrossRef]

4. Tolooiyan, A.; Dyson, A.P.; Karami, M.; Shaghaghi, T.; Ghadrdan, M. Application of Ground Penetrating Radar (GPR) to Detect Joints in Organic Soft Rock. Geotech. Test. J. 2019, 42, 257-274. [CrossRef]

5. Hao, J.; Li, X.; Song, Y.; Zhang, P.; Liu, H. Analysis of mining roadway with large deformation of broken soft coal and research on supporting technology: A case study in Xin'an coal mine, China. Eng. Fail. Anal. 2021, 130, 105761. [CrossRef]

6. Zhao, Q.; Zhang, N.; Peng, R.; Ll, G.; Han, C.; Guo, Y. Discrete Element Simulation of Roadway Stability in an Efflorescent Oxidation Zone. Adv. Civ. Eng. 2018, 2018, 4183748. [CrossRef]

7. Jiang, B.; Wang, L.; Lu, Y.; Gu, S.; Sun, X. Failure Mechanism Analysis and Support Design for Deep Composite Soft Rock Roadway: A Case Study of the Yangcheng Coal Mine in China. Shock Vib. 2015, 2015, 452479. [CrossRef] 
8. Wang, D.; Jiang, Y.; Sun, X.; Luan, H.; Zhang, H. Nonlinear Large Deformation Mechanism and Stability Control of Deep Soft Rock Roadway: A Case Study in China. Sustainability 2019, 11, 6243. [CrossRef]

9. Sun, Y.; Li, G.; Zhang, J.; Xu, J. Failure Mechanisms of Rheological Coal Roadway. Sustainability 2020, 12, 2885. [CrossRef]

10. Huang, Q.; Wang, X.; Chen, X.; Qin, D.; Chang, Z. Evolution of Interior and Exterior Bearing Structures of the Deep-Soft-Rock Roadway: From Theory to Field Test in the Pingdingshan Mining Area. Energies 2020, 13, 4357. [CrossRef]

11. Li, W.; Liu, J.; Chen, L.; Zhong, Z.; Liu, Y. Roadway Support in Deep "Three-Soft" Coal Seam: A Case Study in Yili Mining Area, China. Shock Vib. 2021, 2021, 8851057. [CrossRef]

12. Guo, S.; Zhu, X.; Liu, X.; Duan, H. A Case Study of Optimization and Application of Soft-Rock Roadway Support in Xiaokang Coal Mine, China. Adv. Civ. Eng. 2021, 2021, 3731124. [CrossRef]

13. Li, G.; Ma, F.; Guo, J.; Zhao, H.; Liu, G. Study on deformation failure mechanism and support technology of deep soft rock roadway. Eng. Geol. 2020, 264, 105262. [CrossRef]

14. Yang, S.; Chen, M.; Jing, H.; Chen, K.; Meng, B. A case study on large deformation failure mechanism of deep soft rock roadway in Xin'An coal mine, China. Eng. Geol. 2017, 217, 89-101. [CrossRef]

15. Sun, X.; Zhao, C.; Zhang, Y.; Chen, F.; Zhang, S.; Zhang, K. Physical model test and numerical simulation on the failure mechanism of the roadway in layered soft rocks. Int. J. Min. Sci. Technol. 2021, 31, 291-302. [CrossRef]

16. Wang, H.; Jiang, C.; Zheng, P.; Zhao, W.; Li, N. A combined supporting system based on filled-wall method for semi coal-rock roadways with large deformations. Tunn. Undergr. Space Technol. 2020, 99, 103382. [CrossRef]

17. Ru, W.; Hu, S.; Ning, J.; Wang, J.; Gu, Q.; Guo, Y.; Zuo, J. Study on the Rheological Failure Mechanism of Weakly Cemented Soft Rock Roadway during the Mining of Close-Distance Coal Seams: A Case Study. Adv. Civ. Eng. 2020, 2020, 8885849. [CrossRef]

18. Hou, C.; Zhang, Y.; Yan, Y. Effects of coal seam dip angle on the outburst in coal roadway excavation. Int. J. Min. Sci. Technol. 2019, 29, 757-764. [CrossRef]

19. Tao, Z.; Zhu, C.; Zheng, X.; Wang, D.; Liu, Y.; He, M.; Wang, Y. Failure mechanisms of soft rock roadways in steeply inclined layered rock formations. Geomat. Nat. Hazards Risk 2018, 9, 1186-1206. [CrossRef]

20. Wu, G.; Chen, W.; Jia, S.; Tan, X.; Zheng, P.; Tian, H.; Rong, C. Deformation characteristics of a roadway in steeply inclined formations and its improved support. Int. J. Rock Mech. Min. 2020, 130, 104324. [CrossRef]

21. Sun, Y.; Bi, R.; Chang, Q.; Taherdangkoo, R.; Zhang, J.; Sun, J.; Huang, J.; Li, G. Stability Analysis of Roadway Groups under Multi-Mining Disturbances. Appl. Sci. 2021, 11, 7953. [CrossRef]

22. Zang, C.; Chen, Y.; Chen, M.; Zhu, H.; Qu, C.; Zhou, J. Research on Deformation Characteristics and Control Technology of Soft Rock Roadway under Dynamic Disturbance. Shock Vib. 2021, 2021, 6625233. [CrossRef]

23. Chen, Y.; Li, Q.; Pu, H.; Wu, P.; Chen, L.; Qian, D.; Shi, X.; Zhang, K.; Mao, X. Modeling and Simulation of Deformation Mechanism of Soft Rock Roadway considering the Mine Water. Geofluids 2020, 2020, 8812470. [CrossRef]

24. Sun, Y.; Li, G.; Zhang, J.; Yao, B.; Qian, D.; Huang, J. Numerical Investigation on Time-Dependent Deformation in Roadway. Adv. Civ. Eng. 2021, 2021, 4280139. [CrossRef]

25. Mo, S.; Sheffield, P.; Corbett, P.; Ramandi, H.L.; Oh, J.; Canbulat, I.; Saydam, S. A numerical investigation into floor buckling mechanisms in underground coal mine roadways. Tunn. Undergr. Space Technol. 2020, 103, 103497. [CrossRef]

26. Shi, L.; Zhang, H.; Wang, P. Research on Key Technologies of Floor Heave Control in Soft Rock Roadway. Adv. Civ. Eng. 2020, 2020, 8857873. [CrossRef]

27. Wang, C.; Li, G.; Gao, A.; Shi, F.; Lu, Z.; Lu, H. Optimal pre-conditioning and support designs of floor heave in deep roadways. Geomech. Eng. 2018, 14, 429-437.

28. Ma, Z.; Liang, X.; Fu, G.; Zou, Y.; Chen, A.; Guan, R. Experimental and numerical investigation of energy dissipation of roadways with thick soft roofs in underground coal mines. Energy Sci. Eng. 2021, 9, 434-446. [CrossRef]

29. Zhang, M.; Jiang, F. Rock burst criteria and control based on an abutment-stress-transfer model in deep coal roadways. Energy Sci. Eng. 2020, 8, 2966-2975. [CrossRef]

30. Zhao, C.; Li, Y.; Liu, G.; Meng, X. Mechanism analysis and control technology of surrounding rock failure in deep soft rock roadway. Eng. Fail. Anal. 2020, 115, 104611. [CrossRef]

31. Wang, H.; Jiang, C.; Zheng, P.; Li, N.; Zhan, Y. Deformation and failure mechanism of surrounding rocks in crossed-roadway and its support strategy. Eng. Fail. Anal. 2020, 116, 104743. [CrossRef]

32. Yu, K.; Ren, F.; Puscasu, R.; Lin, P.; Meng, Q. Optimization of combined support in soft-rock roadway. Tunn. Undergr. Space Technol. 2020, 103, 103502. [CrossRef]

33. Zhan, Q.; Zheng, X.; Du, J.; Xiao, T. Coupling Instability Mechanism and Joint Control Technology of Soft-Rock Roadway with a Buried Depth of 1336 m. Rock Mech. Rock Eng. 2020, 53, 2233-2248. [CrossRef]

34. Lu, H.F.; Zhang, Q.Z. Investigations on Shear Properties of Soft Rock Joints under Grouting. Rock Mech. Rock Eng. 2021, 54, 1875-1883. [CrossRef]

35. Sun, Y.; Li, G.; Zhang, J. Investigation on jet grouting support strategy for controlling time-dependent deformation in the roadway. Energy Sci. Eng. 2020, 8, 2151-2158. [CrossRef]

36. Sun, Y.; Li, G.; Zhang, J.; Qian, D. Experimental and numerical investigation on a novel support system for controlling roadway deformation in underground coal mines. Energy Sci. Eng. 2020, 8, 490-500. [CrossRef]

37. Kanji, M.A. Critical issues in soft rocks. J. Rock Mech. Geotech. 2014, 6, 186-195. [CrossRef] 
38. Wang, H.; Zheng, P.; Zhao, W.; Tian, H. Application of a combined supporting technology with U-shaped steel support and anchor-grouting to surrounding soft rock reinforcement in roadway. J. Cent. South Univ. 2018, 25, 1240-1250. [CrossRef]

39. Yang, X.; Wang, E.; Wang, Y.; Gao, Y.; Wang, P. A Study of the Large Deformation Mechanism and Control Techniques for Deep Soft Rock Roadways. Sustainability 2018, 10, 1100. [CrossRef]

40. Zhang, W.; He, Z.; Zhang, D.; Qi, D.; Zhang, W. Surrounding rock deformation control of asymmetrical roadway in deep three-soft coal seam: A case study. J. Geophys. Eng. 2018, 15, 1917-1928. [CrossRef] 